\title{
The Role of Lingnan Arts and Crafts in the Teaching of Arts and Crafts in Colleges and Universities
}

Bo Bai

Guangdong University of Foreign Studies, Guangzhou 510006, Guangdong, China. E-mail: baibo_2004@126.com

Abstract: With the continuous development and progress of modern society, people's pursuit of life is also becoming higher and higher, especially for the quality construction in the field of culture and art. With the increasing public concern, the aesthetic requirements of culture and art have become more brand new. As the main training base of modern social art talents, colleges and universities should not only pay attention to the accumulation and application of students' art professional knowledge, but also combine the development situation of modern society in real time to effectively improve the comprehensive cultural literacy ability of students.

Keywords: Lingnan Arts and Crafts; Colleges and Universities; Arts and Crafts; Teaching; Role

Lingnan culture is a regional culture with distinctive characteristics, brilliant colors and vitality in Chinese culture ${ }^{[1]}$. Due to the traditional arts and crafts are mostly from the folk, and inherited with the folk, under the vigorous development of culture and economy, people have paid more attention to it, and at the same time, they have a higher pursuit for the development of culture and art. Therefore, in the process of art education, colleges and universities can carry out the appropriate integration teaching of Lingnan arts and crafts and professional art knowledge in real time, which can not only provide the latter with more rich art materials, but also make students more intuitive understanding to the traditional arts and crafts, in order to improve the students' comprehensive cultural literacy, and further strengthen the their cultural identity. It has a more direct impact on students' future development in the field of art. Combining with the practical significance of Lingnan arts and crafts in college art teaching, this paper puts forward several reasonable application ways and gives a simple exposition for the basic problems existing in the teaching of arts and crafts in colleges and universities at this stage for reference.

\section{The basic problems existing in the teaching of arts and crafts in colleges and universities at this stage}

In terms of the actual teaching effect of arts and crafts majors in colleges and universities, there is still a big gap between them and the demand of modern society for the cultivation of art talents. In the process of arts and crafts teaching, teachers pay more attention to the explanation of daily professional knowledge and the teaching of art skills, ignoring the cultivation of students' inheritance and understanding of art, which makes most students lack of certain artistic thinking ability. With the continuous impact of the information network, due to the teachers do not give full play to the advantages of guidance, students have a certain ideological deviation on the nature of arts and crafts, resulting in many excellent traditional arts and crafts are not understood by students, students cannot really feel the actual charm and value of arts and crafts, which is quite unfavorable for artistic thinking development for students to a certain extent.

Copyright(C) 2020 Bo Bai

doi: 10.18686/ahe.v4i10.2875

This is an open-access article distributed under the terms of the Creative Commons Attribution Non-Commercial License (http://creativecommons. org/licenses/by-nc/4.0/), which permits unrestricted non-commercial use, distribution, and reproduction in any medium, provided the original work is properly cited. 
In addition, teachers themselves lack a certain understanding of the traditional arts and crafts. They do not make more targeted teaching plans and teaching objectives in real-time combination with the development situation of modern society, thus cannot fundamentally and effectively meet the pursuit of students for the spirit of art. Finally, students' thinking mode is single and solidified, which makes it difficult to have a more profound understanding of arts and crafts, and hinders the development of students in the field of art.

\section{The importance of Lingnan arts and crafts in the teaching of arts and crafts in colleges and universities}

\subsection{It is beneficial for students to maintain artistic vitality and create a city of arts and crafts}

In modern society, art as a commodity must be combined with market demand if it wants to maintain long-term vitality. Lingnan arts and crafts are no exception. It is also one of the important ways for the sustainable development of Lingnan folk art to absorb modern design elements while maintaining its own characteristics. Therefore, colleges and universities as the training base of arts and crafts talents, in the teaching process of arts and crafts, teachers integrate Lingnan arts and crafts with professional art education, which can not only give full play to the practical value of arts and crafts, but also help students understand the charm of arts and crafts more deeply. It enables the traditional arts and crafts to be more widely inherited and carried forward, so that students can actively participate in the process of exploring the connotation of arts and crafts, and create more meaningful arts and crafts works under the continuous stimulation of traditional arts and crafts, as well as always maintain the vitality of traditional Lingnan arts and crafts. Teachers take a more innovative way to integrate Lingnan arts and crafts into the fine arts education in colleges and universities, which can not only provide more abundant teaching resources for art education in colleges and universities, but also help students feel the vigor and vitality of traditional arts and crafts more intuitively, so as to make students' artistic spirit field more colorful and carry out art for students artistic creation with more inspiration. On the other hand, the traditional Lingnan arts and crafts in the development process of art education in colleges and universities get more comprehensive protection and innovation, which is conducive to the further inheritance and development of Lingnan arts and crafts.

\subsection{It is conducive to the cultivation of students' comprehensive artistic quality}

The creation of every exquisite product takes time and energy, and the spirit of craftsmanship is the core of modern design. With the continuous development of society in various fields at this stage, the way for students to receive education information is more and more network-based, which makes the essence of art not fully displayed. In the process of artistic creation, it is inevitable to become an assembly line operation. Therefore, if teachers want to improve the related problems in the current art education more quickly, it is an inevitable trend for the development of the future education field to adopt the innovative teaching of the combination of traditional Lingnan arts and crafts and college art education, which can not only better help students understand the actual value of art creation, but also make students enjoy the process of arts and crafts creation. In the process of exploring the art field, we should better cultivate our own independent thinking mode, further strengthen our professional skills through more practice, and constantly improve our comprehensive artistic quality.

In addition, the field of art creation in modern society is more and more extensive, especially the all-round development of information technology, which provides a new way for the creation of arts and crafts. The integrating teaching of Lingnan arts and crafts and college art education can also provide teachers with more diversified ideas for professional teaching hours, so as to more effectively promote the quality of art education in colleges and universities. The quantity efficiency has been improved more comprehensively, and the students' innovative thinking is better cultivated, so that the vitality of artistic life is always maintained.

\section{The innovative application of Lingnan arts and crafts in the teaching of arts and crafts in college and universities}

First of all, colleges and universities should fully realize the differences between the creation of arts and crafts works, appropriately set up the corresponding teaching curriculum system according to the teaching characteristics of arts and crafts specialty, and formulate more targeted teaching planning, as well as take more innovative teaching strategies according to the 
development concept of modern society in real time, so as to effectively improve the teaching quality and efficiency of arts and crafts major in colleges and universities, and meet the training needs of art talents in modern society more efficiently. Therefore, teachers can appropriately abandon the traditional art classroom culture teaching mode, innovate teaching measures that are more suitable for students' actual learning needs, and integrate the most representative Lingnan arts and crafts science into the art teaching of colleges and universities, so as to better develop students' creative ideas, and at the same time, enable students to be more intuitive in folk arts and crafts with the visual impact, more calm thinking about the actual value of arts and crafts, in order to better adjust their own creative characteristics, and provide more options for its future development in the art field.

Secondly, teachers can make full use of the information network platform technology, establish the corresponding official art sharing platform, and place more artistic works on the platform, so as to facilitate students to have real-time cultural exchange and more quickly collide with artistic inspiration, that helps students better define their own artistic style. in order to better enhance the vitality of Lingnan folk arts and crafts, teachers can appropriately integrate it with the needs of modern society. In the process of professional arts and crafts teaching, we can organize more activities which are more close to the real life, and use the network platform for proper publicity, so that more students can actively participate in the understanding of folk arts and crafts, and truly understand the true meaning and charm of art. In the process of participating in the activities, students can not only have a more profound and comprehensive understanding of China's folk arts and crafts, but also stimulate students' inner rich creative ideas by appreciating arts and crafts works, and then more enthusiastically invest in the exploration of arts and crafts field. In this way, we can not only better teach students to create more correct arts and crafts works, but also make the characteristics of Lingnan arts and crafts continue to be maintained.

\section{Conclusion}

In summary, teachers can make full use of the natural advantages of China's traditional arts and crafts to help students understand the charm of arts and crafts more intuitively in the process of carrying out culture and art teaching. Lingnan culture, as one of the regional cultures with characteristics and vitality of Chinese traditional arts and crafts, is of great significance to the teaching of fine arts in colleges and universities. It can not only bring students a stronger visual impact, stimulate students' artistic creation inspiration, but also make students have a deeper understanding of China's excellent traditional culture, in order to promote the inheritance and development of traditional arts and crafts.

\section{References}

1. Zhu J. Brief analysis on the inheritance and development of Chinese folk art. Popular Literature and Art (Theory) 2008; (9).

2. Li Q. On the value and function of folk art in art education in colleges and universities. Grand Stage 2013; (10). 